\title{
UNIVERSITYOF
}

FORWARD

THINKING

WESTMINSTER用

WestminsterResearch

http://www.westminster.ac.uk/westminsterresearch

Financialisation of News in China in the Age of the Internet: The Case of Xinhuanet

Xin, $X$.

This is a copy of the accepted author manuscript of the following article: Xin, X. (2018) Financialisation of News in China in the Age of the Internet: The Case of Xinhuanet. Media, Culture and Society, 40 (7), pp. 1039-1054. The final definitive version is available from the publisher Sage at:

https://doi.org/10.1177/01634437177455121

(C) The Author(s) 2017

The WestminsterResearch online digital archive at the University of Westminster aims to make the research output of the University available to a wider audience. Copyright and Moral Rights remain with the authors and/or copyright owners.

Whilst further distribution of specific materials from within this archive is forbidden, you may freely distribute the URL of WestminsterResearch: ((http://westminsterresearch.wmin.ac.uk/)).

In case of abuse or copyright appearing without permission e-mail repository@westminster.ac.uk 
Journal of

Media, Culture \& Society

\section{Financialisation of News in China in the Age of the Internet: The Case of Xinhuanet}

\begin{tabular}{|c|l|}
\hline Journal: & Media Culture and Society \\
\hline Manuscript ID & Draft \\
\hline Manuscript Type: & Original Article \\
\hline Keyword: & $\begin{array}{l}\text { Xinhuanet, financialisation, Chinese media, media conglomeration, Xinhua } \\
\text { News Agency, state-owned news organisation }\end{array}$ \\
\hline Abstract: & $\begin{array}{l}\text { This paper discusses the recent development of Xinhuanet.com, a news } \\
\text { website launched by Xinhua News Agency, one of China's key central state- } \\
\text { owned news organisations. Xinhuanet Co. Ltd., the business entity running } \\
\text { the website, went public in October 2016 in Shanghai. This marked the first } \\
\text { step in the state news agency's financialisation. Two main questions are } \\
\text { addressed. First, what were the main driving forces behind Xinhuanet's } \\
\text { transformation from a governmental cultural organisation to a state-owned } \\
\text { publicly traded enterprise, the majority shareholder of which remains } \\
\text { Xinhua? Second, how should the nature of this transformation be } \\
\text { understood, in relation to Xinhua's wider marketisation process and that of } \\
\text { the Chinese media sector as a whole? The paper argues that Xinhua's } \\
\text { financialisation via Xinhuanet is best understood as part of a state- } \\
\text { administrated initiative in accord with Xinhua's own business ambitions. } \\
\text { The financialisation of news by state players such as Xinhuanet does not } \\
\text { alter the underlying ownership structure of Chinese news media, which } \\
\text { remain ultimately state-controlled. }\end{array}$ \\
\hline
\end{tabular}

\section{SCHOLARONE" \\ Manuscripts}




\title{
Financialisation of News in China in the Age of the Internet: The Case of Xinhuanet
}

\author{
Introduction \\ The financial sector is increasingly playing a central role not only in many countries' \\ macroeconomics and economic policies, but also in daily life (Harvey, 2007; \\ Lapavitsas, 2013; Lapavitsas and Powell, 2013). Inevitably, it has begun to exert its \\ hegemonic influence on the production and circulation of news and current affairs. \\ Bill Grantham and Toby Miller (2010:176) have vividly described what the \\ phenomenon of financialisation of news and current affairs looks like in a liberal \\ democracy:
}

...stories are presented in terms of their monetary significance to investors. Leading news sources rely on finance reporting for much of their revenue. Business advisors dominate discussion on dedicated finance cable stations such as CNBC and Bloomberg and are granted the status of seers when they appear on MSNBC, CNN, and the networks. The focus of "news" has become stock markets, earnings, profits, and portfolio management. Journalists stalk politics in order to discredit democratic activities that might restrain capital. Labour news has been transmogrified into corporate news, and politics is measured in terms of its reception by business. Even the recent crisis has not eroded journalistic faith in reactionary solutions to a radical problem, as the bizarre press coverage of the meltdown indicates...

Behind the financialised "look" of news, the core of the change brought about by the financialisation process lies in the ultimate shift in the pattern of capital accumulation as well as the logic of running businesses (Lapavitsas, 2013). Financialisation arguably leads to the tendency that "profit-making occurs increasingly through financial channels rather than through trade and commodity production" (Krippner, 2005:174). In other words, a multinational media corporation, for example, once it is completely financialised, will be able to "profit[ing] without producing", at least in theory (Lapavitsas, 2013: 792-805).

From a Marxist perspective, the emergence of financialisation in mature capitalist economies in the mid-1970s can be explained by the theory of surplus absorption: as the surplus derived from capitalist production became difficult to absorb by the 1970s, the financial sector rose to prominence and created all sorts of novel speculative financial tools to absorb/channel the surplus (Lapavitsas, 2013). However, the cause, content and form of the financialisation can vary from country to country according to different political, historical, institutional and social conditions (Lapavitsas and Powell, 2013). Financialisation in less developed economies has been largely seen as an outcome of financial globalisation, which has resulted in a rise in the volume of foreign capital flowing from advanced economies into less developed countries. Moreover, the accumulation of foreign exchange reserves has also stimulated the process of financialisation in the emerging economies. Despite its Marxist origin, financialisation remains a vaguely defined term in social science (Lapavitsas and Powell, 2013). In this paper, the term is employed broadly to refer to the tendency towards the increasing hegemonic power exerted by the financial sector on the non- 
financial sector in general and the media and communication sector specifically in the process of marketisation and globalisation.

In the context of globalisation, the tendency towards financialisation of news, though still largely relevant to advanced economies, is now taking shape in less developed countries, such as China. However, little research has been done in the Chinese context (for one of the few exceptions, see Wang, 2017). In mainland China, the most influential state-owned news institutions, such as Xinhua News Agency, while largely maintaining their propaganda function, have been trying to financialise themselves in a way which is similar to what Grantham and Miller (2010) describe about their Western counterparts. Moreover, the government, led by the Communist Party of China (CPC), has been pressing them to speed up the transformation process since 2009. To start with, the Chinese government approved and supported the public floatation of an important part of their businesses - Internet-based news operations. Yet, the causes of such a big move and its implications for Chinese media transformations have not been systematically studied.

Against this background, this paper focuses on the case of Xinhuanet.com, a news website launched by the state news agency, Xinhua, in the late 1990s. Xinhuanet Co. Ltd., the business entity running the website, went public in October 2016 in Shanghai. This has marked a new milestone in the state news agency's transformation towards financialisation, though it is still at a very early stage of development. Two main questions are addressed in this paper. First, what were the main driving forces behind Xinhuanet's transformation from a governmental cultural organisation to a state-owned publicly traded enterprise, the majority shareholder of which remains Xinhua? Second, how should the nature of this transformation be understood, in relation to Xinhua's wider marketisation process and that of the Chinese media sector as a whole?

The analytical focus on a state-owned news organisation is what differentiates this paper from a recent study published by Xia and Fuchs (2017), one of the few Englishlanguage studies on media financialisation in China, which instead focuses on privately-owned news portals and other Internet companies. Under China's current media and Internet regulatory framework, privately owned companies are banned from publishing self-produced original news content online. Instead, they have to rely on news produced by state-owned news sources. Thus, the financialisation of the privately-owned Internet companies has had only an indirect impact on news operations in mainland China. It is also worth noting that, until recently, only the nonnews businesses of state-owned news institutions were allowed to be commercialised. By October 2016, Xinhuanet had its own editorial staff, consisting of over 700 members, including a large number of journalists licensed by the Chinese news authorities. Thus, Xinhuanet's financialisation via the 2016 public floatation actually involved the commercialisation of news operations. Xinhuanet is the second stateowned news website to go public in the country, following People.cn, the official website of People's Daily, which become a listed company in 2012. In comparison with People.cn, Xinhuanet's transformation was more complex, having gone through more ups and downs, along with the fluctuations of the Chinese stock market and changes in policy during the most recent decade. In this sense, the study of Xinhuanet is indicative of the extent to which it is possible to combine the status of state news agency with a developing journalism orientation that aims to serve the increasingly 
influential financial sector, including shareholders. In seeking to answer the two key questions, the paper proceeds first by providing an overview of the debate on the nature of Chinese media transformation, in order to situate this study within its academic context.

\section{The Nature of Chinese Media Transformations}

Numerous studies have discussed media, communication and cultural transformation in China, a process underway since the start of the reform age in the late 1970s. The key question that scholars have grappled with is: how to understand the nature of the reforms initiated by Deng Xiaoping and then continued by his successors over the past four decades? This issue is essential for understanding the nature of the transformations in Chinese media in general and of state-supported media financialisation in particular.

As Yuezhi Zhao (2008: 106) points out, the changes in Chinese media generally, and the state-engineered media conglomeration commencing from the late 1990s specifically, have brought into sharp focus not only the theoretical issues that surround "the potentially conflictual relationship between the party and the state", but also practical problems caused by "the complicated ways in which the 'territorial' and 'capitalist' logics of power overlap, intertwine, and tug against each other at the central and local levels of the Chinese state". In these circumstances, it is not surprising that many scholars have questioned the seemingly self-evident definition of "socialism with Chinese characteristics" (Zhao, 2008). Instead, they have described what China has evolved into over the past 40 years variously as "state capitalism" (Bremmer, 2008), "market socialism" (Amin, 2005; Hsu, 2007), "market Leninism" (Wright, 1994), "postsocialist experiments" (Rofel, 2013) or "commercialisation without independence" (Chan, 1993).

For David Harvey, Deng's reforms equate to "neoliberalism with Chinese characteristics". They comprise of both "neoliberal elements" and "authoritarian centralised control" (Harvey, 2005: 120; cited by Zhao, 2008: 5). On the one hand, China has evidently embraced the neoliberal model of capitalist development in the process of integrating itself into the global capitalist system since the early 1980s (Harvey, 2007). As a result of that, the problem of over-accumulation characterised by overinvesting, overbuilding, overproduction and environmental degradation has occurred in China too (Harvey, 2007; Xia and Fuchs, 2017). On the other hand, state repression, though not unique to China, has always been apparent in the country (Harvey, 2007; Zhao, 2008). In fact, the party-state has in recent years further tightened its authoritarian centralised control over key sectors, including the media and communication sector - the traditional ideological territory of the ruling party (Zhao, 2015a). Thus, many scholars are inclined to describe what China has been doing as "state capitalism" (Xia and Fuchs, 2017). However, the party-state has never openly committed itself to neoliberalism but to socialism with Chinese characteristics or a socialist market economy (Zhao, 2008). In this sense, the case of China along with many other cases (e.g. the former Soviet Union) seems to indicate that the relationship between socialism and democracy might be as problematic as that between capitalism and democracy (Zhao, 2008).

For Samir Amin, socialism in China has not yet lost out to capitalism: "As long as the principle of equal access to land is recognised and is effectively implemented, it is not 
too late for social action to successfully influence an as yet uncertain evolution" (Amin, 2005: 274-5). In line with Amin, Arrighi suggests that "the nature of development in China is not necessarily capitalist" in spite of "the spread of market exchanges in the pursuit of profit" (Arrighi, 2007: 24). He also recognises that this "does not mean that socialism is alive and well in Communist China, nor that it is a likely outcome of social action". In comparison with Arrighi, Lin Chun's view on the future outcome of China's reforms seems more optimistic (Lin, 2013). According to Lin, if China manages to overcome its key developmental problems, it will be able to offer a socialist "China model", which will serve as a promising alternative to capitalist development. However, Lin acknowledges many social problems that China needs to overcome, ranging from rising inequality to environmental degradation, from the decline of public services to the rise of urban unemployment (Lin, 2006 and 2013).

In agreement with Amin, Arrighi (2007: 24) contends, "even if socialism has already lost out in China, capitalism, by this definition, has not yet won". More importantly, Arrighi (2007:24) sees "the social outcome of China's titanic modernisation effort" as an "indeterminate" process. Therefore, he suggests that "socialism and capitalism as understood on the basis of past experience may not be the most useful notions with which to monitor and comprehend the evolving situation" in China (Arrighi, 2007: 24). Arrighi also acknowledges that there has been "a new awareness among a growing group of scholars that there is a fundamental world-historical difference between processes of market formation and process of capitalist development" (Arrighi, 2007: 24). In this sense, the confusions about "the relationship between market economy, capitalism, and economic development", exemplified by the case of China, are "as much theoretical as they are practical" and "it is entirely possible, indeed likely, that they will be resolved in practice before they are resolved in theory" (Arrighi, 2007:17).

Yet, this does not mean that discussing theoretical concerns associated with China's economic and social transformations is not worthwhile, including more specifically those undergone by the media, communication and cultural sector. Quite the opposite, Arrighi's suggestion on how to deal with the theoretical confusions generated by Chinas unique trajectory is a call for developing new theoretical perspectives to provide more adequate explanations of social realities in countries other than the US and the UK. With a similar goal in mind, a number of communication scholars have called for the de-Westernising of communication studies, drawing on cases from diverse geopolitical locations and cultural backgrounds, including China (Curran and Park, 2000; Fuchs, 2016; Thussu, 2009; Waisbord and Mellado, 2014). More recently, there has been a call for international communication scholars to broaden their horizons and take into account the ongoing global power shift accelerated by the rise of the BRICS (Brazil, Russia, India, China and South Africa) (Nordenstreng and Thussu, 2015; Zhao, 2015a and 2015b). As a key player in this grouping, China has unavoidably become a focus of debate in discussions on the BRICS. In this context, there is growing attention on how Chinese media are seeking to exert more influence on the outside world, marking a move away from an exclusive focus on Western media's influence on China (Zhao, 2015a). The effort by the Chinese state "in projecting its soft power through its media and communication systems" has thus become a popular research subject in recent years (Zhao, 2015a: 23). It is also the case that every step that a state-owned central media institution like Xinhua takes towards conglomeration and marketisation can now be explained and justified in 
relation to the state's soft power ambitions. However, the "soft power" concept itself is not without theoretical flaws, and arguably looking at contemporary developments through the soft power theoretical lens has prevented gaining an understanding of the more nuanced changes to Chinese media and journalism (Sparks, 2015; Zhao, 2013). This "soft-power-for-all" approach certainly does not help gain a full picture of the Chinese media, consisting of "a huge and complex set of institutions" (Sparks, 2012:65). Thus, as suggested by Colin Sparks (2012:65), it is important "to try to understand all of their [Chinese media] aspects if we want to understand Chinese society, and particularly if we wish to discover some sense of the potential and likely direction of change". In keeping with this recommendation, this paper looks into a relatively under-researched aspect of media development in contemporary China, a phenomenon also overlooked in earlier research on Xinhua (Author removed, 2006 and 2012).

\section{Why Did Xinhuanet Go Public?}

On $28^{\text {th }}$ October 2016 Xinhuanet launched its initial public offering (IPO) on the Shanghai Stock Exchange. This was just a month after receiving official approval for the IPO, for which Xinhua had prepared for six years (Xinhua, 2016b) ${ }^{1}$. After such a long time waiting, the timing of the IPO did not seem to be favourable to Xinhuanet. In January 2016 turmoil had just hit the country's stock exchanges hard and there had been spill-over effects on the major global markets (Allen and Phillips, 2016). In addition, the country's economy was continuing to slow down. According to Chinese official statistics, the country's gross domestic product (GDP) grew by $6.7 \%$ in 2016 in comparison with $6.9 \%$ a year earlier, reaching the lowest level since 1990 (BBC, 2017). The deepening of China's economic slowdown, described as the "New normal" by Chinese authorities, triggered a new round of debate about China's future and its likely contribution to the already turbulent world economy (Peston, 2015). In contrast to China's general economic slowdown, however, its Internet economy was still booming (Xia and Fuchs, 2017). According to Alexa, an American websiteranking service, seven of the world's top 20 Internet companies in 2017 were based in mainland China ${ }^{2}$. The vast majority of them (19 out of 20) are non-state-owned. The domestic Internet market is dominated by three key players, namely Baidu, Alibaba and Tencent (BAT) - all publicly-traded companies. However, from around 2010 and especially after 2015, there has also been a start-up boom (Xia and Fuchs, 2017). On the one hand, BAT continues to monopolise the domestic industry via acquisitions and financial investments. On the other hand, the government encourages young graduates to start up their own businesses in order to offset the short-term social impact of increased unemployment resulting from the economic slow-down. BAT's ongoing process of monopolist accumulation via acquisitions and financial investments in tandem with the start-up boom is arguably stimulating the Internet bubble in China, increasing the volatility of the country's stock market (Xia and Fuchs, 2017). In terms of market share, Xinhuanet can be placed alongside other state-controlled news websites (the so-called "state players"), in-between the above two categories. In its list of top Chinese and global websites (as of the end of April 2017), Alexa ranked Xinhuanet in $28^{\text {th }}$ place and $151^{\text {st }}$ place respectively. ${ }^{3}$ Although Xinhuanet was ahead of People.cn and many other Chinese state players in terms of popularity (as measured by site traffic), it still lagged far behind non-state-owned Chinese news portals such as sohu.com and sina.com.cn. Given all these factors, 2016 was arguably not the best year for Xinhuanet to go public. So how is it possible to account for Xinhuanet's decision to go public nevertheless? 
First of all, there are profit-maximising motives behind any IPO (Fuchs, 2011). Such was the case for Xinhuanet's. In its 2016 IPO prospectus Xinhuanet stated that the company aimed to raise nearly $\mathrm{RMB}^{4} 1.5 \mathrm{bn}$ (US $\$ 230 \mathrm{~m}$ ) of capital, accounting for $25 \%$ of its total shares (Xinhua, 2016a). Xinhuanet's fund-raising target for its IPO was compatible with People.cn's. The latter raised nearly RMB1.4bn (US\$219m) of capital from its 2012 IPO, almost three times more than the original target (Rabinovitch, 2012). Undoubtedly, People.cn's successful IPO set a good precedent for Xinhuanet. According to Xinhuanet's IPO document, the funds raised via the IPO would be used for the company's future infrastructure and business investments, including expanding the company's multimedia business, cloud service, mobile Internet service and online education (Xinhua, 2016b). Xinhuanet's business incentives thus can be explained by Karl Marx and his followers' theory of capital accumulation via financialisation: it was a decision grounded on the "money that produces money" formula (Marx 1894: 515; Xia and Fuchs, 2017:4). However, since Xinhuanet remains a majority state-owned company even after becoming a publiclytraded company, it still has to justify its profit-maximising strategies, especially when the latter are in conflict with the website's function of serving the party-state's ideology. Moreover, it is also important to note that Xinhuanet anticipated that the capital generated by the IPO was unlikely to cover the full cost of the proposed new projects and stated that if needed would raise extra funds through other means (Xinhuanet, 2016).

Even if the profit incentives are clear, becoming a publicly traded company at a turbulent moment was a risky way of financing Xinhuanet (Yang, 2016). The Chinese stock market has certain distinctive characteristics, a brief review of which can help gain a better understanding of Xinhuanet's move towards capitalisation. Firstly, China's stock market is still playing a relatively small role in financing the country's real economy. In 2015 only 5\% of total financing flows to the country's real economy came from the domestic stock market (Yang, 2016). Thus, even a big fall, like the one of $23 \%$ which occurred in early 2016, has little impact on China's economy in spite of its spill-over effect on global markets (Yang, 2016). Secondly, stocks issued in China, particularly A shares that are priced in Chinese local currency (Renminbi or RMB), tend to be valued higher than those issued in Hong Kong and the US. This is especially the case for the shares of cultural and media enterprises. In 2015 the average Price/Earnings (P/E) ratio ${ }^{5}$ of A shares in China was 17.61, but in the cultural and media sector -- almost 100, nearly six times the P/E ratio of the shares issued by similar companies in Hong Kong and the USA (Publishers, 2016). This highly speculative aspect of the Chinese stock market makes it relatively easy for companies like Xinhuanet to raise funds via IPO in mainland China. However, this feature, by making the Chinese stock market particularly volatile, also means that listed companies face higher risk (Xia and Fuchs, 2017).

Still, the reasons identified and discussed so far cannot fully justify Xinhuanet's move. This especially was the case in the circumstances, as the aftermath of the most recent turmoil was still being felt and the next one seemed likely to be under way (Xia and Fuchs, 2017). The next question arising then is: Did Xinhuanet have at its disposal an alternative way to raise funds for its future development?

A review of Xinhuanet's financial data and capital operations prior to its IPO in 2016 
suggests a positive answer to this question. Before going public, Xinhuanet was the second most profitable enterprise owned by Xinhua. Since 2011 there has been a steady rise in the company's annual income and net profit (Xinhuanet, 2014 and 2016). In 2013 Xinhuanet contributed about $8 \%$ of Xinhua's total annual revenue, earning RMB460m (about US\$66.7m) in business revenue and RMB167m (about US $\$ 24.2 \mathrm{~m}$ ) in net profit. The last two figures rose respectively by $39.4 \%$ and $22.8 \%$ year on year. In the first three quarters of 2016, Xinhuanet's revenue grew by $47 \%$ in comparison with the previous year, reaching RMB795m (about US $\$ 115.3 \mathrm{~m}$ ). The net profit attributable to initial shareholders amounted at RMB161m (about US\$23.3m), a growth of $6 \%$ compared to the same period in 2015. Xinhuanet's major source of revenue came from online advertising, contributing RMB348m (about US $\$ 50.5 \mathrm{~m}$ ) or $55 \%$ of the company's total income in 2014. The other main sources of revenue included information services, website maintenance and technical support and mobile Internet services. In addition, Xinhuanet received governmental subsidies, amounting to $9 \%$ of its annual net profit between 2011 and 2013. Xinhuanet took also an active part in capital operations in recent years, including while waiting for its IPO. In March 2015 Xinhuanet invested RMB70m (about US\$10.2m) to for purchasing 5,42 million stock shares of Shanghai YC Culture Media Co. Ltd., an online advertising service provider in China. Later that year, in June, Xinhuanet invested another RMB130m (about US\$18.9m) to establish the Xinhua Kangmei Healthcare Thinktank Co. Ltd. in collaboration with Kangmei Pharmaceutical Co. Ltd. (Qian, 2016). These two major investments suggest that Xinhuanet had sufficient funds for business operations prior to the IPO (Qian, 2016).

It is worth noting that the total amount of funds raised by Xinhuanet via the IPO was much more than the company's annual operating income between 2011 and 2016. However, this also implies more business risks for Xinhuanet to take on for the reasons explained earlier. On $6^{\text {th }}$ March 2017 Xinhuanet's market capitalisation reached RMB17.151bn (about US\$2.49bn), nearly three times the value of Xinhua's total annual income in $2015^{6}$. Xinhuanet's P/E ratio was 47.46 , much higher than, for instance, Thompson Reuters's 31.96. The latter's market capitalisation on $6^{\text {th }}$ March 2017 was about US\$31.16bn ${ }^{7}$. As I will discuss in the following section, Xinhua's main goal for many years had been reaching the status of global news agency on a par with Reuters (currently Thomson Reuters). To some extent, this continues to be Xinhua's chief aspiration.

In short, the discussion so far has argued that profit-maximising incentives only partly explain Xinhuanet's move towards financialisation. In order to gain a better understanding of the driving forces behind the process, and the main implications for Xinhua's development as a whole, it is necessary to review briefly the history of Xinhuanet in the context of the marketisation and conglomeration Xinhua has undergone over the past four decades.

\section{From Marketisation to Financialisation}

Prior to the launch of Xinhuanet, Xinhua endeavoured to become a financially independent news institution by 2000, willingly receiving a reduced amount of governmental subsidies each year for nearly two decades (Author removed, 2012). Throughout this period, fighting for financial independence was part of Xinhua's ambition to become a "world-class news agency", comparable with the likes of Reuters and Associated Press (AP). Given its state ownership, conceivably financial, 
rather than editorial, independence was seen as an achievable goal. Gaining financial independence was also seen as instrumental in offsetting the negative impact of state ownership on Xinhua's credibility overseas. Xinhua was certainly not the only news agency to be concerned about both its ownership status and its sources of financing. In fact, even Reuters, before going public in the 1980s, believed that its private ownership status put it at a disadvantage vis-à-vis AP, a cooperative news agency (see Read, 1999).

Until today, however, Xinhua has not yet achieved complete financial independence from state subsidies (Author removed, 2012). The process of marketisation Xinhua has undergone over the past four decades has led to a mixed pattern of financing. In 2016 over $50 \%$ of Xinhua's annual income was generated by the agency itself and the rest came from state subsidies (Xinhuanet, 2016). This mixed pattern of financing has been widely adopted by state-owned Chinese media organisations over the past forty years. On the one hand, the state's financial support enables state-run news organisations like Xinhua to survive in an increasingly competitive news market. On the other hand, it helps the CPC to justify its control over news content production. However, neither the government nor state-owned news organisations see state subsidies as an optimal form of financing media conglomerates "with Chinese characteristics". In these circumstances, both the government and the state-owned news institutions like Xinhua started looking for a new source of financing in late 2008 and early 2009. I shall elaborate this point in the following section.

Despite Xinhua's ambition, Xinhuanet was not conceived as a well-designed business venture for the news agency. As withPeople.cn, Xinhuanet was established as part of the state's top-down efforts to enhance its online propaganda activities targeting foreign audiences in the late 1990s (Peng, 2005; Wei, 2016). In other words, Xinhuanet was born to serve the CPC's ideological purposes. In addition to its ideological function, Xinhuanet's business and journalistic functions emerged and then evolved along with Xinhua's own business and news strategies in the 2000s, especially since 2009 (Author removed, 2006 and 2012).

On $7^{\text {th }}$ November 1997 Xinhua officially launched its news website, xinhua.org, renamed xinhuanet.com in 2000 (Xinhuanet, 2014; Xinhua, 2006c). It took a couple of years for Xinhua to figure out what to do with the website. On $1^{\text {st }}$ November 2000, the State Council's Information Office (SCIO) and the then Ministry of Information Industry of China announced "Interim Provisions on the Administration of Internet Websites Engaged in News Posting Operations". According to the document, "any website which intends to post news articles on the Internet must first receive a permit from the government" ${ }^{\text {" }}$. Only news websites owned and run by existing state-owned news organisations, such as Xinhuanet and People.cn, were permitted to produce original news content as well as post news produced by their own journalists. In December 2000 Xinhuanet was granted a permit by the SCIO to produce and post news online. Meanwhile, Xinhua updated its website, and started using the website to release news online, mostly produced by its own journalists.

Serving mostly as a free information window on China as part of the state's online foreign propaganda project, Xinhuanet's popularity was in some ways in tension with Xinhua's news wholesale business, still based on offline wire services in the early 2000s. Via Xinhua's website, individual Internet users were able to access Xinhua's 
main news coverage directly without the agency of other retail news outlets, such as newspapers and TV stations. For traditional news agencies like Xinhua, which mostly remained invisible in the offline world, releasing news online was a big step towards becoming less dependent on other media outlets to reach out to audiences directly in the online world. Invisibility used to be one of the major concerns of Xinhua journalists, due to its negative impact on the issue of "news landing" in the offline environment (Author removed, 2012). For Xinhua, however, the greater visibility gained online via Xinhuanet in addition to the provision of free online access to the agency's main news coverage inevitably clashed with the interests of the media outlets subscribing to Xinhua's wholesale news. Both Xinhua and Xinhuanet tried to minimize such conflicts. One of the main solutions was to run the website as a business unit separated from the main editorial and wire news provision sectors of Xinhua. Another solution was to let the website establish its own editorial team, differentiating the content of Xinhuanet's own news releases from that of Xinhua's wire news. This approach later also helped Xinhua to fully explore the website's business potential, especially after 2009 .

Firstly, Xinhuanet gained personnel independence from Xinhua's headquarters. This was a crucial step for Xinhuanet to transform itself from a government-affiliated institution into an enterprise. In 2010, the state quota on the size of Xinhuanet's staff, especially regarding the number of "party cadres" employed, was removed (Xinhua, 2014). This granted Xinhuanet the autonomy to recruit its general employees, including journalists, according to its own business needs. This also means that Xinhuanet's employees are no longer treated as party-carders - a privileged social status that is still enjoyed by the vast majority of Xinhua's employees. Since 2010, Xinhuanet has expanded quickly. Its current editorial board alone consists of over 700 contract-based employees.

Xinhuanet's journalists are responsible for selecting and editing (mostly) Xinhua news wires for the news website. They are also given more or less the same opportunity as Xinhua's journalists to collect original material for general news reporting, both at home and abroad. However, when it comes to covering politically sensitive events, Xinhuanet's journalists, particularly those who are newly-employed, arguably require "special supervision" from Xinhua/Xinhuanet's senior editors (Yuan, Zhou and Weng, 2014:19). Xinhuanet's editors still have to rely on Xinhua's news wires for guidelines. This, on the one hand, implies that Xinhuanet's directlyrecruited employees are still not seen to be as politically reliable as Xinhua's partycadre-journalists are. On the other hand, this demonstrates that Xinhuanet has gained only a relative editorial autonomy from Xinhua in the process of transformation. In this respect, neither media marketisation nor financialisation has resulted in the editorial independence of Xinhuanet, in spite of the changes in its personnel and financing patterns.

\section{The Party-State's “Unswerving” Support}

Xinhuanet's financialisation, similar to People.cn's, can be seen as "part of the government's push to commercialise the state-controlled news websites to make them more competitive in a fast-changing industry" (Xinhua, 2016a).

Two key documents, issued by the party-state in 2009 and 2011, created an enabling environment for People.cn and Xinhuanet to go public. The first one was unveiled by 
the SCIO in September 2009 as "A working plan for a pilot programme about transforming key news websites into enterprises". The key news websites the document referred to included three central state-owned news websites, namely People.cn, Xinhuanet and CCTV.cn, as well as a number of local state-owned news websites. In these circumstances, both People.cn and Xinhuanet became part of the state's reform experiment to test how far state-owned news organisations could be commercialised without being privatised and how they could remain under the ideological control of the CPC. Two years later, the importance and urgency of the financialisation reform via the pilot programme had been readdressed and further clarified by the Central Committee of the CPC in another document - "Decision of the CPC Central Committee on Major Issues Pertaining to Deepening Reform of the Cultural System and Promoting the Great Development and Flourishing of Socialist Culture". The latter document was unveiled at the Sixth Plenary Session of the Seventeenth CPC Central Committee on $18^{\text {th }}$ October $2011^{9}$. In this document, the party-state under the then leadership of Hu Jintao revealed its ambition to become a global socialist cultural power, in which publicly-owned enterprises would become dominant and coexist with enterprises under other forms of ownership. In order to achieve this, the government and the party expressed their intention that cultural industries in China would become "a pillar industry" by the end of 2015, increasing their share in the country's GDP up to 5\% (Zhang, 2011). To accelerate the development of cultural industries in the country, priority along with "unswerving" support would be given to "state-owned cultural enterprises and those with a controlling share held by the state" for their business expansion (CPCCC, 2011). The types of support from the party-state were specified as follows: "investment approval, loans, land use, tax breaks, stock market financing, bond issues, foreign trade and application for special funds" (CPCCC, 2011). One of the major tasks set between 2011 and 2015 was to "cultivate large and highly competitive state-owned cultural enterprises or enterprise groups and those with a controlling share held by the state, and get them to play a leading role in developing cultural industries" in China (CPCCC, 2011). Non-government capital would be allowed to "participate in the transformation of state-owned for-profit cultural institutions into enterprises", playing a supplementary role "in implementing major cultural projects and constructing cultural industry parks" (CPCCC, 2011). However, non-government capital would remain subject to strict supervision and regulation.

In the meantime, controlling the online public sphere, as China's huge online population kept growing, had become a major concern of the ruling party (Yang, 2009). The two policy documents also served to address such concern, supporting the "most loyal members" of the Internet services, particularly those run by central Party organs, in their efforts to become more competitive vis-à-vis popular commercial news portals such as Sohu and Sina.

The 2011 policy guidelines played a particularly important role in speeding up the process for People.cn to go public. Just a few months after the CPC's Decision was announced, the IPO for People.cn was approved by the China Securities Regulatory Commission (CSRC). The external conditions needed for Xinhuanet to follow suit were also put in place. Against this background, Xinhuanet started its transformation from a governmental cultural organisation to an enterprise. 
However, it took Xinhuanet longer than People.cn to go through this process of internal transformation. Xinhua's reform plan was approved by SCIO in May 2011. In May 2011 Xinhuanet Corporation Ltd. was officially established (Xinhuanet, 2017). In 2012, Xinhuanet first set up its own around-the-clock news centre in addition to Xinhua's existing ones. Then the corporation reformed its shareholding structure, inviting eight new strategic investors - all state-owned or controlled - in addition to Xinhua and its two business affiliations to join in. When Xinhuanet eventually submitted its first IPO application in early 2013, the whole stock market in the country was experiencing a retreat: The CSRC had stopped approving new stock listings in that year. In mid-2014, after the CSRC's approval procedure resumed, Xinhuanet submitted its second application (Xinhua, 2016a). In October 2016, Xinhuanet officially went public on the Shanghai Stock Exchange (Xinhua, 2016c).

As of the end of July of 2017 Xinhua (together with its two business affiliates) still holds nearly 64\% of the shares in Xinhuanet (Xinhuanet, 2017). Furthermore, Xinhuanet's other seven largest shareholders also represent state-run/owned bodies. They now jointly hold over 11\% of Xinhuanet's shares (Xinhuanet, 2017). Among them there are the National Council for Social Security Fund, China Cultural Industries Investment Fund, Nanfang Media Group, Jiangsu Broadcasting Corporation, China Telecommunications Corporation and China Unicom. A process of cross-sector and cross-regional convergence in terms of financing is clearly underway. However, there are strict rules in place establishing under which conditions these state shareholders can sell what percentage of their shares in Xinhuanet and to whom (Xinhuanet, 2016). This minimises the risk that Xinhuanet's financialisation could lead to its privatisation.

\section{Discussion and Conclusion}

The analysis presented in this paper has shown that a number of factors interacted, leading to Xinhuanet's decision to seek a new source of financing through the domestic stock market. In addition to the party-state's top-down policy on media financialisation, relevant factors included Xinhua's long-standing ambition to become a global news agency and more recently its quest for further business expansion in an increasingly competitive news market.

Xinhuanet's financialisation also needs to be understood in the wider context of Chinese media transformation. China's accession to the World Trade Organisation (WTO) in 2001, the long preparation for and the successful hosting of the Beijing Olympics in 2008 and the outbreak of the global financial crisis in the same year - all these events reoriented the priorities of Chinese media in the new millennium $(\mathrm{Hu}$, 2003; Finlay and Xin, 2009; Zhao, 2008, 2015a and 2015b). The state-engineered process of media conglomeration and consolidation started in the mid-1990s. The initial goal was to help Chinese state media to grow bigger and stronger so to enable them to "dance" (read: compete at home) with "the wolves" (read: transnational media conglomerates) (Hu, 2003; Zhao, 2008). Since 2002 the process of media conglomeration has slowed down and has been gradually replaced by the "Going abroad" project. The latter encourages state-owned central and local media, including the newly formed media conglomerates, to expand their business overseas, especially in countries and regions of strategic importance to China, in order to enhance the country's soft power (Zhao, 2013). The "Going abroad" project gained momentum in 2009 when many financially struggling media companies in the West began to cut 
jobs. In the same year Xinhua began to accelerate its international expansion under the "Going abroad" project. By the end of January 2017 Xinhua had established over 180 overseas bureaus in major cities of the world. From reorganising businesses at home to expanding its news infrastructure abroad, Xinhua's trajectory has been largely in line with the major trends of Chinese media transformations in the first decade of the new millennium. During this period, the key rationale behind the decision to let state-run news organisations merge into fewer and bigger media conglomerates has changed too. If in the early 2000s it was primarily a defensive move designed to counter the impact of Western "media imperialism", since 2009 it has been a pro-active move aiming for China to play a leading role in the process of media globalisation. As a result, a new type of media conglomerate, exemplified by Xinhua, has emerged (Boyd-Barrett, 2015).

In addition, Xinhua's financialisation via Xinhuanet, while serving the main purpose of diversifying the state agency's sources of financing, cannot be seen primarily as the natural outcome of market competition and capital accumulation. Rather, it must be seen as part of a state-administrated initiative, which has been in accord with Xinhua's own business ambitions. Thus, unlike Xinhua's earlier efforts to achieve financial independence, which represented mostly a bottom-up initiative by the state news agency, Xinhuanet's recent financialisation is best understood as the outcome of both a top-down state administration and a bottom-up initiative. The ultimate goal of this is to reinforce, instead of weakening, the state news agency's function of serving the party-state's ideology, in addition to its other purposes.

The financialisation of news by state players such as Xinhuanet does not alter the underlying ownership structure of Chinese news media, which remain ultimately state-controlled. As the majority shareholder of Xinhuanet, Xinhua remains a not-forprofit state news agency, still enjoying a monopoly in mainland China. In this respect, the state-supported financialisation, similar to the state-engineered process of conglomeration and marketisation, has not changed the nature of the Chinese media as a whole.

Neither media marketisation nor financialisation has brought Xinhuanet full editorial independence despite the change in its personnel and financing patterns. In spite of the rise of privately owned Internet companies (e.g. BAT), the party-state still largely maintains authoritarian ideological control over online news flows within mainland China in order to the serve the goal to build "socialism with Chinese characteristics". In this sense, both Amin and Arrighi are right in suggesting that capitalism has not won in the country. This is at least the case as far as the media sector is concerned. Meanwhile, the still tight centralised authoritarian ideological control reminds the rest of world how far "socialism with Chinese characteristics" is from Marx"s socialist project.

Nevertheless, the public float of Xinhuanet and People.cn has certainly opened up a road for the financial sector to intervene in the battle for hegemonic control over online news flows in China. How will the process of financialisation of news be unfolded in China in the years to come? Will it lead to further media concentration, similar to the situation found in more developed media markets, such as the US and the UK (McChesney, 2015; Paterson, 2005)? What will be the impact on news 
content? Further research on Xinhuanet and People.cn needs to be done in order to answer these questions.

\section{Notes}

1. Xinhuanet firstly applied for an IPO in early 2013, but its application was suspended as the China Securities Regulatory Commission (CSRC) stopped approving new stock listings in the year. The second application was submitted in mid-2014 after the CSRC's approval procedure resumed. 2. http://www.alexa.com/topsites accessed on 29 April 2017.

3. http://www.alexa.com/siteinfo/xinhuanet.com accessed on 29 April 2017.

4. RMB (Renminbi) is the official currency of the People's Republic of China (PRC). 1 Renminbi was approximately equivalent to 0.14 US Dollar according to XE Currency Converter. http://www.xe.com/currencyconverter/convert/?From= \&To=CNY accessed on 2 May 2017. 5. Price/Earnings ratio is calculated by dividing the current stock price of a listed company by its earnings per share. Price refers to the company's current stock price, while earnings refers to its net profit per share for the most recent twelve-month period.

6. http://www.google.com.hk/finance?q=SHA:603888 accessed on 6 March 2017.

7. https://uk.finance.yahoo.com/quote/TRI.TO?1tr=1 accessed on 6 March 2017.

8. https://www.cecc.gov/prior-restraints accessed on 27 February 2017.

9. http://www.cctb.net/bygz/wxfy/201111/W020111121519527826615.pdf accessed on 20 March 2017.

\section{References}

Allen K and Phillips T (2016) China turmoil takes toll on global stocks in turbulent start to 2016. Available at: https://www.theguardian.com/business/2016/jan/08/chinaeconomy-global-stock-markets-share-prices (accessed on 2 March 2017).

Amin S (2005) China, Market Socialism, and U.S. Hegemony. Review (Fernand Braudel Center) 28(3): 259-279.

Arrighi G (2007) Adam Smith in Beijing: Lineages of the Twenty-First Century. London: Verso.

BBC (2017) China's economy grows $6.7 \%$ in 2016. Available at: http://www.bbc.co.uk/news/business-38686568 (accessed on 3 March 2017).

Boyd-Barrett O (2015) Media Imperialism. London: Sage.

Bremmer I (2008) The Return of State Capitalism. Survival 50(3): 55-64. DOI: $10.1080 / 00396330802173198$

Communist Party of China Central Committee (CPCCC) (2011) Decision of the CPC Central Committee on major issues pertaining to deepening reform on the cultural system and promoting the great development and flourishing of socialist culture, passed at the Sixth Plenary Session of the Seventeenth CPC Central Committee on 18 October 2011. Available at:

http://www.cctb.net/bygz/wxfy/201111/W020111121519527826615.pdf (accessed on 18 January 2017).

Chan JM (1993) Commercialisation without Independence: Trends and Tensions of Media Development in China. In: Cheng, JY and Brosseau, M (eds.) China Review 1993. Hong Kong: Chinese University Press, pp. 25.1-25.21. 
Curran J and Park MJ (2000) Beyond Globalisation Theory. In: Curran, J and Park, MJ (eds.) De-Westernising Media Studies. London: Routledge, pp. 3-18.

Finlay CJ and Xin X (2010) Public Diplomacy Games: A Comparative Study of American and Japanese Responses to the Interplay of Nationalism, Ideology and Chinese Soft Power Strategies around the 2008 Beijing Olympics. Sport in Society: Cultures, Commerce, Media, Politics 13(5): pp. 876-900.

Fuchs C (2011) Foundations of Critical Media and Information Studies. London: Routledge.

Fuchs C (2016) Baidu, Weibo and Renren: The Global Political Economy of Social Media in China. Asian Journal of Communication 26(1): 14-41.

Grantham B and Miller T (2010) The End of Neoliberalism. Popular Communication 8(3): 174-177.

Harvey D (2005) A Brief History of Neoliberalism. Oxford, N.Y.: Oxford University Press.

Harvey D (2007) Neoliberalism as Creative Destruction. The ANNALS of the American Academy of Political and Social Science 610(1): 21-44.

Hu ZR (2003) The Post-WTO Restructuring of the Chinese Media Industries and the Consequences of Capitalisation. Javnost-The Public: Journal of the European Institute for Communication and Culture 10(4):19-36.

Hsu CL (2007) Creating Market Socialism: How Ordinary People are Shaping Class and Status in China. London: Duke University Press.

Krippner GR (2005) The financialisation of the American Economy. Socio-Economic Review 3(2): 173-208.

Lapavitsas C (2013) The Financialisation of Capitalism: 'Profiting without Producing'. City 17(6): 792-805.

Lapavitsas C and Powell J (2013) Financialisation Varied: A Comparative Analysis of Advanced Economies. Cambridge Journal of Regions, Economy and Society 6(3): 359-379.

Lin C (2006) The Transformation of Chinese Socialism. London: Duke University Press.

Lin C (2013) China and Global Capitalism: Reflections on Marxism, History, and Contemporary Politics. New York: Palgrave Macmillan.

Marx K (1894) Capital: Volume III. London: Penguin.

McChesney RW (2015) Rich Media, Poor Democracy: Communication Politics in Dubious Times. New York: The New Press. 
Nordenstreng K and Thussu DK (eds.) (2015) Mapping BRICS media. New York: Routledge.

Paterson C (2005) News Agency Dominance in International News on the Internet. In: Skinner, D., Compton, J. and Gasher, M. (eds.) Converging Media, Diverging Politics: A Political Economy of News in the United States. Lanham, MD: Lexington, pp.145-164.

Peston R (2015) What is China's 'new normal'? Available at:

http://www.bbc.co.uk/news/business-34344926 (accessed on 3 March 2017).

Peng L (2005) The First Decade of China's Internet Media (in Chinese). Beijing: Tsinghua University Press.

Qian CZ (2016) Xinhuanet as another state media player went public with twists and turns (in Chinese). Available at: http://finance.sina.com.cn/stock/roll/2016-09-25/docifxwevmf2183670.shtml (accessed on 1 March 2017).

Rabinovitch S (2012) People's Daily website IPO raises \$219m. Available at: https://www.ft.com/content/9f927c42-8ace-11e1-912d-00144feab49a (accessed on 1 March 2017).

Read D (1999) The Power of News: The History of Reuters. Oxford, UK: Oxford University Press.

Rofel L (2013) Grassroots Activism: Non-normative Sexual Politics in Post-socialist China. In: Sun, W and Guo Y (eds.) Unequal China: The political economy and cultural politics of inequality. London: Routledge, pp.154-167.

Sparks C (2012) Beyond Political Communication: Towards a Broader Perspective on the Chinese Press. Chinese Journal of Communication 5(1): 61-67.

Sparks C (2015) China, Soft Power and Imperialism. In: Rawnsley GD and Rawnsley MT (eds.) Routledge Handbook of Chinese Media. London: Routledge, pp. 27-46.

Thussu D (ed.) (2009) Internationalising Media Studies. New York, NY: Routledge.

Wang J (2017) “Stir-Frying” Internet Finance: Financialisation and the Institutional Role of Financial News in China. International Journal of Communication 11(2017): 581-602.

Waisbord S and Mellado C (2014) De-westernising Communication Studies: A Reassessment. Communication Theory 24(4): 361-372.

Wei WH (2016) Is the rise of the Chinese portal because of the "good system"? (in Chinese). Available at:

http://www.ftchinese.com/story/001068693?full=y\&ccode=2G168003 (accessed on 27 February 2017)

Wright E (1994) To be Rich is Glorious. World Press Review 41(7): 10-11. 
Xia BQ and Fuchs C (2017) The Financialisation of Digital Capitalism in China. London: Westminster Institute for Advanced Studies. https://www.westminster.ac.uk/the-westminster-institute-for-advancedstudies/publications/westminster-advanced-studies

Author removed (2006)

Author removed (2012)

Xinhua (2016a) China's Xinhuanet gets approval for going public in Shanghai. Available at: http://www.chinadaily.com.cn/business/201609/24/content_26883610.htm (accessed on 3 March 2017).

Xinhua (2016b) Xinhuanet debuts on Shanghai Stock Exchange. Available at: http://news.xinhuanet.com/english/china/2016-10/28/c_135783652.htm (accessed on 3 March 2017).

Xinhua (2016c) Xinhuanet launches IPO in Shanghai. Available at: http://www.chinadaily.com.cn/business/2016-10/28/content_27202997.htm (accessed on 3 March 2017).

Xinhuanet (2014) Xinhuanet Co. Ltd. draft stock prospectus submitted to China Securities Regulatory Commission on 27 June 2014 (in Chinese). Available at: http://www.csrc.gov.cn/pub/zjhpublic/G00306202/201406/P02014062750516171746 3.pdf (accessed on 3 March 2017).

Xinhuanet (2016) Xinhuanet Co. Ltd.'s official stock prospectus (in Chinese). Available at: http://download.xinhuanet.com/zonghe/xhnews/xhwgkagzgsms.pdf (accessed on 5 February 2017).

Xinhuanet (2017) Xinhuanet Co. Ltd.'s equity structure. Available at: http://www.xinhuanet.com/company/equity-structure.htm (accessed on 1 May 2017).

Yang, GB (2009) The Power of the Internet in China: Citizen Activism Online. New York: Columbia University Press.

Yang Y (2016) What stock market turmoil means for China's economy. Available at: https://www.ft.com/content/9062c7da-c379-11e5-808f-8231cd71622e (accessed on 7 March 2017).

Yuan J, Zhou G and Weng W (2014) A New Experiment for Integrating Information in News Articles from Various Sources In the Month of Justice. Journalistic Practice 2: 17-19 (in Chinese).

Zhang XM (2011) The $12^{\text {th }}$ Five-Year Plan: to promote the culture industry and turn it into a "pillar industry" (in Chinese). Available at:

http://www.cassrccp.com/uploads/soft/130326/8. 学者专栏频道资料/张晓明/_十二 五_推动文化产业上升为支柱产业_张晓明.pdf accessed on 1 March 2017. 
Zhao YZ (2008) Communication in China: Political Economy, Power, and Conflict. Lanham, Maryland: Rowman \& Littlefield.

Zhao YZ (2013) China's Quest for "Soft Power": Imperatives, Impediments and Irreconcilable Tensions? The Public/Javnost: Journal of the European Institute for Communication and Culture 20(4): 17-30.

Zhao YZ (2015a) (Re)-Focusing on the Target: Reflections on a Trajectory of Studying the Chinese Media. In: Rawnsley GD and Rawnsley MT (eds.) Routledge Handbook of Chinese Media. London: Routledge, pp. 9-26.

Zhao YZ (2015b) The BRICS Formation in Reshaping Global Communication: Possibilities and Challenges. In: Nordenstreng K and Thussu DK (eds.) Mapping BRICS media. New York: Routledge, pp. 66-86. 